\title{
Report of a critical recombination further narrowing the TSC1 region
}

\author{
Kit-Sing Au, Jill Murrell, Alan Buckler, Susan H Blanton, Hope Northrup
}

\begin{abstract}
A large tuberous sclerosis multigenerational family segregating with markers on chromosome 9q from the TSC1 region was studied with a new highly polymorphic marker (designated A6) from the region. A critical affected person showed recombination with the marker, eliminating approximately 100 kilobases from the telomeric end of the critical region, which contains three genes and three to four additional exons for which the associated genes have not been delineated. This information serves to further the search for the TSC1 gene.
\end{abstract}

(f Med Genet 1996;33:559-561)

Key words: tuberous sclerosis complex (TSC); TSC1; chromosome 9q; polymorphism.
Division of Medical

Genetics,

Department of

Pediatrics,

University of Texas

Medical School

Houston, 6431 Fannin,

Houston, Texas 77030 ,

USA

K-S Au

H Northrup

Molecular

Neurogenetics Unit,

Massachusetts General

Hospital and

Department of

Genetics, Harvard

Medical School,

Boston,

Massachusetts, USA

J Murrell

A Buckler

Department of

Pediatrics,

University of Virginia,

Charlottesville,

Virginia, USA

$S$ H Blanton

Correspondence to:

Dr Northrup.

Received 5 December 1995

Revised version

accepted for publication

28 February 1996

Tuberous sclerosis complex (TSC) is an autosomal dominantly inherited disease with a population frequency of 1 in 6000 to 1 in $10000 .^{1-4}$ Efforts to isolate the causative gene(s) by positional cloning have been under way for a number of years with initial linkage reported to chromosome $9 \mathrm{q}$ in $1987 . .^{5} \mathrm{TSC}$ is well documented as exhibiting locus heterogeneity, with one locus on chromosome $9 q$ (TSC1) and another on $16 \mathrm{p}$ (TSC2). ${ }^{6-9}$ The TSC 2 gene has been cloned ${ }^{10}$ and work towards characterisation is in progress. ${ }^{11-13}$ The TSC1 gene on chromosome $9 \mathrm{q}$, despite being localised first, has continued to elude investigators. One difficulty with cloning the TSC1 gene has been in narrowing its location to facilitate the isolation and testing of candidate genes. There are few large kindreds available with recombinant subjects to aid in narrowing the region.

We have studied a large kindred, previously reported in less detail, ${ }^{6}$ with 12 DNA markers from the TSC1 region and five DNA markers (including an intragenic TSC2 polymorphism) from the TSC2 region. Studies of the family yield a maximum two point lod score of 4.68 at $\theta=0.0$ with a marker from the TSC 1 region (table). Linkage of the family is excluded by

Two point lod scores in family HOU-4 for TSC and chromosome $9 q$ markers

\begin{tabular}{llllll}
\hline Locus & \multicolumn{5}{l}{ Lod scores at indicated recombination fraction $(m=f)$} \\
\cline { 2 - 6 } & 0.00 & 0.05 & 0.10 & 0.20 & 0.30 \\
\hline ASS & 4.68 & 4.31 & 3.92 & 3.07 & 2.11 \\
D9S64 & 3.48 & 3.20 & 2.90 & 2.26 & 1.53 \\
DBH & 4.68 & 4.31 & 3.92 & 3.07 & 2.11 \\
D9S66 & 0.90 & 0.81 & 0.72 & 0.52 & 0.30 \\
D9S114 & $-x$ & 2.49 & 2.47 & 2.07 & 1.46 \\
D9S67 & $-x$ & 0.47 & 1.05 & 1.27 & 1.04 \\
\hline
\end{tabular}

markers from the TSC2 region, including an intragenic TSC2 polymorphism. By studying the family with a previously undescribed polymorphic marker (designated A6) on chromosome $9 \mathrm{q}$, we have eliminated a large portion of the TSC1 region from consideration, aiding in the continuing search for the TSC1 gene.

\section{Methods}

CLINICAL ASSESSMENT OF FAMILY MEMBERS All family members have been carefully examined for signs of TSC. Before assignment of TSC gene status, at risk subjects underwent careful physical examination including Wood's light examination of the skin, dilated retinal examination, CT scan or MRI study of the brain, renal ultrasound, and echocardiogram. Some family members have been followed and re-examined several times over the course of an eight year period (II $\cdot 4$, II 6 , II $\cdot 10$, III 13 , III 14 , III 15 , III 16 , III 17 , III 19 , III $\cdot 21$, III·22, III 23$)$. Disease status has been assigned in all family members. Results of diagnostic studies are summarised in fig 1 .

LINKAGE STUDIES FOR CHROMOSOMES 9 AND 16 Twelve dinucleotide repeat markers were tested including four associated with genes (gelsolin $(\mathrm{GSN}),{ }^{14}$ the Abelson oncogene (ABL), ${ }^{15}$ argininosuccinate synthetase (ASS), ${ }^{16}$ and dopamine $\beta$-hydroxylase $\left.(\mathrm{DBH})^{17}\right)$. Of the remaining eight tested, five (D9S65, D9S64, D9S66, D9S114, and D9S67) map to $9 \mathrm{q} 34^{18}$ and the other three (D16S525, D16S291, and D16S283) map to $16 \mathrm{p} .{ }^{19}$

Five additional markers were tested including ABO $,{ }^{20} \mathrm{Col} 5 \mathrm{~A} 1,{ }^{21}$ TSC2EcoRV (TSC2 intragenic marker), ${ }^{13} \mathrm{D} 16 \mathrm{~S} 83$, and $\mathrm{A} 6$. ABO, Col5A1, and the TSC2EcoRV polymorphism were all tested by PCR amplification, restriction enzyme digestion, and electrophoresis on an agarose gel. D16S83 and A9 were tested by Southern blotting analysis (modified from Martin $e t a l^{2}$ ).

The newly discovered marker, $\mathrm{A} 6$, is a $1.7 \mathrm{~kb}$ $H i n d I I I / E c o$ RI DNA fragment isolated from cosmids $\mathrm{c} 01$ and $\mathrm{c02}$ located in the TSC1 critical region, as reported by Murrell et al. ${ }^{23}$ The physical mapping information indicates that A6 is located approximately $100 \mathrm{~kb}$ proximal to D9S114 and $200 \mathrm{~kb}$ distal to D9S66. On testing 22 unrelated subjects, A6 detects a HindIII polymorphism with at least 12 alleles ranging in size from 4.5 to $10 \mathrm{~kb}$ (data not shown). Eighteen of 23 members of HOU-4 were tested with A6 (fig 2). No result was 


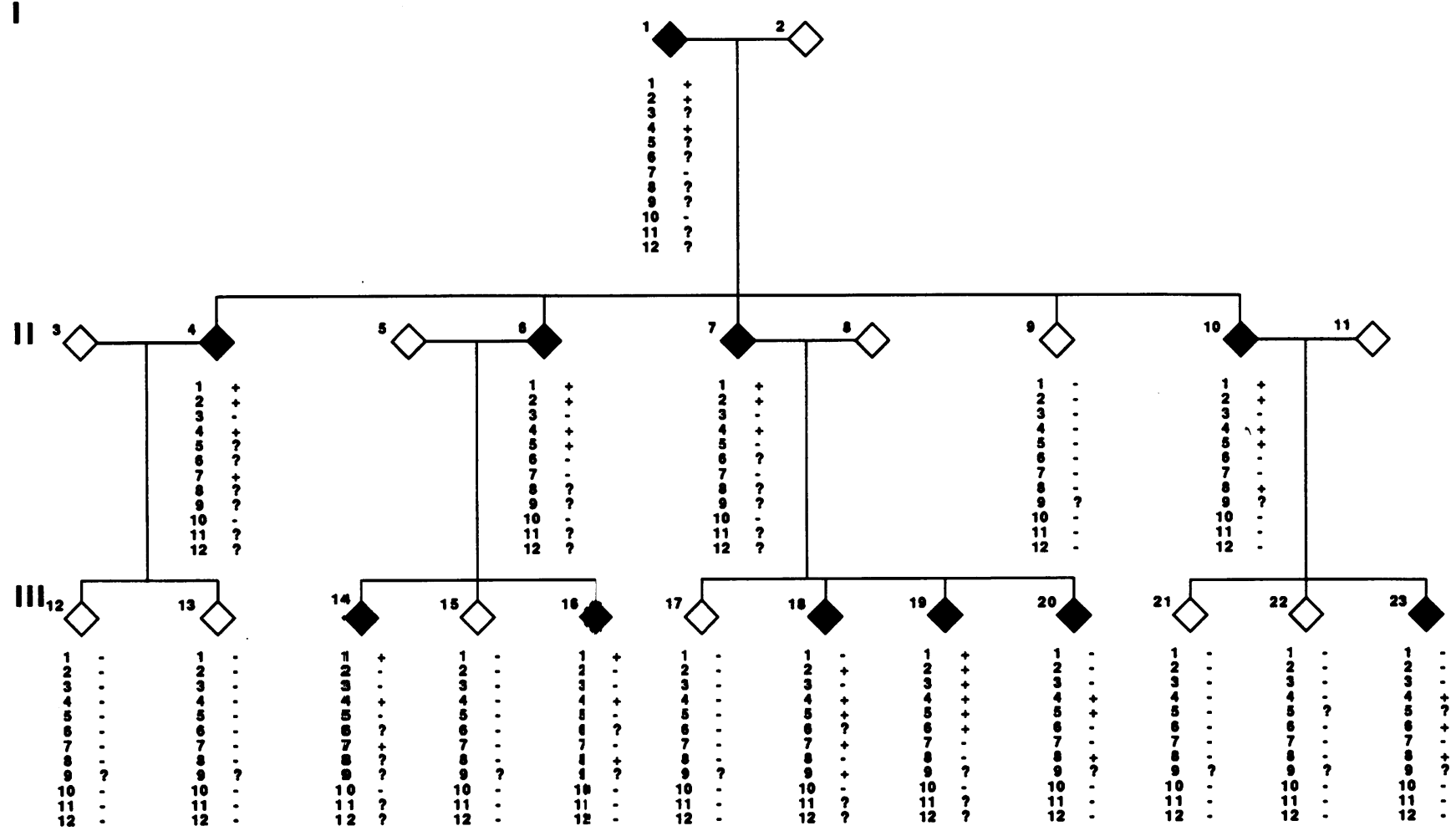

Figure 1 Chromosome 9 linked tuberous sclerosis pedigree. Affected people are indicated by solid diamonds and $+1-$ refers to diagnostic findings as follows: (1) facial angiofibroma, (2) periungual fibromas, (3) shagreen patches, (4) hypopigmented macules, (5) retinal lesions (phakomata or achromic patches or both), (6) cardiac rhabdomyomata, (7) seizures, (8) brain CT findings of TSC (calcified subependymal nodules), (9) brain MRI achromic patches or both), (6) cardiac rhabdomyomata, (7) seizures, (8) brain CT findings of TSC (calcified subependymal nodules), (9) brain is unknown.

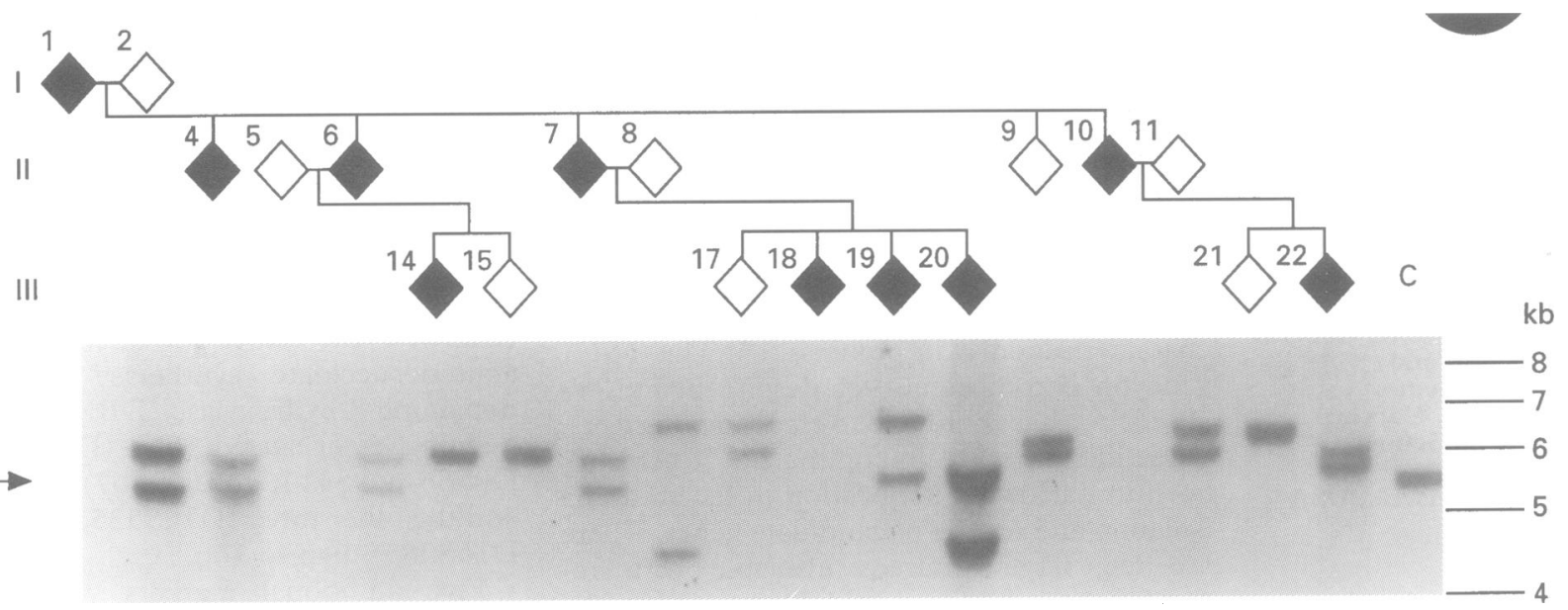

Figure 2 Southern blot of DNA from members of family HOU-4. All affected subjects have a band at $5 \cdot 8 \mathrm{~kb}$ with the exception of III 14 whose chromosomes have undergone a recombinational event.

obtained on four subjects (I· $1, \mathrm{II} \cdot 5, \mathrm{II} \cdot 10$, and III.18); however, genotypes on these people are not critical to our conclusions. We were able to determine the genotype on seven affected subjects including the critical recombinant subject, III·14. Map position for all markers was as indicated in recent published reports for chromosomes 9 and $16 .{ }^{192425}$

\section{Results}

Loci tested on chromosome $16 \mathrm{p}$ included (centromere to telomere): D16S283, D16S291, the TSC2 gene (exon 40), D16S83, and D16S525. D16S83 excluded linkage to $\theta=0.07$, the
TSC2 gene excluded linkage to $\theta=0.025$, and D16S291 excluded linkage to $\theta=0 \cdot 16$. Haplotyping the five markers showed no crossovers, excluding the entire region causing TSC in this family.

Haplotypes generated for chromosome $9 q$ are indicated in fig 3 . The grandparental haplotype segregating with TSC is boxed. Crossover events have occurred in II $\cdot 10$, III $\cdot 14$, and III $\cdot 19$. II $\cdot 10$ and III 19 indicate recombination with Col5A1, eliminating it as a candidate gene. III 14 has had a crossover event detected with the new polymorphic marker (fig 2), eliminating the DNA telomeric as harbouring the TSC1 gene. 
$\mathbf{I}$
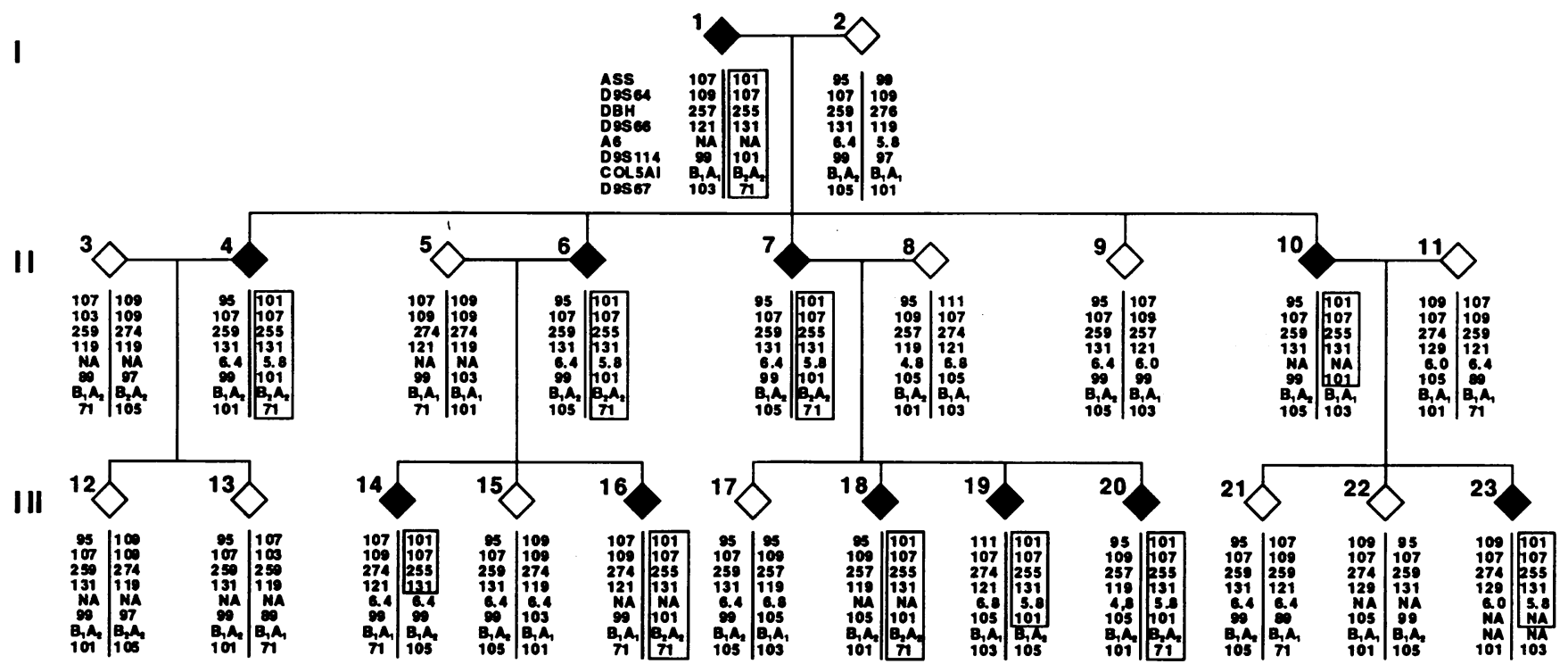

Figure 3 Pedigree of family HOU-4 with results of chromosome 9q markers haplotyped beneath each person. The affected haplotype has been boxed indicating the recombinational event.

\section{Discussion}

The large family described here shows strong evidence of linkage to the TSC1 gene while eliminating the TSC2 gene as causative. Unlike a previous study seeking to accomplish a similar aim, narrowing of the TSC1 critical region using a large chromosome 9 linked family and critical recombinants, ${ }^{26}$ the key recombinant subject (III-14) in our family is definitely affected with TSC. It is therefore valid to use the information generated to narrow the TSC1 critical region further. By testing A6, a newly discovered polymorphic marker from the region, we have eliminated 100 kilobases and three genes from the telomeric end of the critical region (Murrell et al, submitted). The reported findings help in the continuing search for the TSC1 gene.

We wish to thank the members of family HOU-4 for their participation over many years in TSC research. K-SA is the recipient of a Postdoctoral Fellowship from the National Tuberous Sclerosis Association. The work was supported by NIH grants NS32300-01 and RR-02558-08Al to HN.

1 Gomez MR. Tuberous sclerosis. New York: Raven Press, 1988. 2 Ahlsén G, Gilberg IC, Lindblom R, Gilberg C. Tuberous sclerosis in western Sweden. Arch Neurol 1994;51:76-81.

3 Osborne JP, Fryer AE, Webb D. Epidemiology of tuberous sclerosis. Ann NY Acad Sci 1991;615:125-7.

4 Wiederholt WC, Gomez MR, Kurland LT. Incidence and prevalence of tuberous sclerosis in Rochester, Minnesota: 1950 through 1962. Neurology 1985;35:600-3.

5 Fryer AE, Chalmers A, Connor JM, et al. Evidence that the gene for tuberous sclerosis is on chromosome 9. Lancet gene for tuberous
$1987 ; \mathbf{i}: 659-61$

6 Northrup H, Kwiatkowski DJ, Roach ES, et al. Evidence for genetic heterogeneity in tuberous sclerosis: one gene locus on chromosome 9 and at least one locus elsewhere.

7 Sampson JR, Scahill SJ, Stephenson JBP, Mann L, Connor JM. Aspects of tuberous sclerosis in the west of Scotland. f Med Genet 1989;26:28-31.

8 Haines JL, Amos J, Attwood J, et al. Genetic heterogeneity in tuberous sclerosis: study of a large collaborative dataset. Ann NY Acad Sci 1991;615:256-64.

9 Kandt RS, Haines JL, Smith M, et al. Linkage of an important gene locus for tuberous sclerosis to a chromosome
16 marker for polycystic kidney disease. Nature Genet 1992;2:37-41.

10 European Chromosome 16 TSC Consortium. Identification and characterization of the tuberous sclerosis gene on chromosome 16. Cell 1993;75:1305-15.

11 Kumar A, Wolpert C, Kandt RS, et al. A de novo frameshift mutation in the tuberin gene. Hum Mol Genet 1995; 4:1471-2.

$12 \mathrm{Xu} \mathrm{L}$, Sterner C, Maheshwar MM, et al. Alternative splicing of the tuberous sclerosis 2 (TSC2) gene in human and of the tuberous sclerosis 2 (TSC2) gene

13 Au K-S, Rodriguez JA, Rodriguez E Jr, Dobyns WB, Delgado MR, Northrup $H$. Mutations and polymorphisms in the tuberous sclerosis complex gene on chromosome 16 Hum Mutat (in press)

14 Kwiatkowski DJ, Perman S. Dinucleotide repeat polymorphism at the GSN locus (9q32-34). Nucleic Acids Res 1991;19:967.

15 Kwiatkowski DJ. Dinucleotide repeat polymorphism at the ABL locus (9q34). Nucleic Acids Res 1991;19:967.

16 Kwiatkowski DJ, Nygaard TG, Schuback DE, et al Identification of a highly polymorphic microsatellite VNTR within the arginosuccinate synthetase locus: exclusion of the dystonia gene on 9q32-34 as the cause of doparesponsive dystonia in a lare kindred. $A m \mathcal{F}$ Hum $\mathrm{Geme}$ responsive dystonia in a large kindred. Am f Hum Genet

7 Porter CJ, Niahmia J, Wolfe J, Craig IW. Dinucleotide repeat polymorphism at the human dopaine beta-hydroxylase (DB\#) locus. Nucleic Acids Res 1992;20:1429.

18 Kwiatkowski DJ, Henske ED, Weimerk K, Ozelius L, Gusella JF, Haines J. Construction of a GT polymorphism map of human 9 q. Genomics 1992;12:229-40

19 Kozman HM, Keith TP, Donis-Keller H, et al. The CEPH consortium map of human chromosome 16. Genomics 1995;25:44-58.

20 Yamamoto FI, Clausen $\mathrm{H}$, White T, Marken J, Hakomori SI. Molecular genetic basis of the histo-blood group ABO system. Nature 1990;345:229-33.

21 Greenspan DS, Pasquinelli AE. Bst UI and Dpn II RFLPs at the COL5A1 gene. Hum Mol Genet 1994;3:385.

22 Martin A, Northrup H, Ledbetter D, et al. Prenatal detection of rec(5), dup,q,inv(5)(p13q33) using DNA analysis, flow cytometry, and in situ hybridization to supplement classical cytometry, and in situ hybridization to supplement classical

23 Murrell J, Trofatter J, Rutter M, et al. A 500-kilobase region containing the tuberous sclerosis locus (TSC1) in a 1.7 megabase YAC and cosmid contig. Genomics 1995;25 $59-65$

24 Povey S, Armour J, Farndon P, et al. Report on the Third International Workshop on Chromosome 9. Ann Hum Genet 1994;58:177-250.

25 Shen Y, Kozman HM, Thompson A, et al. A PCR-based genetic linkage map of human chromosome 16. Genomics 1994;22:68-86.

26 Nellist M, Brook-Carter PT, Connor JM, Kwiatkowski DJ, Johnson P, Sampson JR. Identification of markers flanking the tuberous sclerosis locus on chromosome 9 (TSC1). $\mathscr{f}$ Med Genet 1993;30:224-7. 